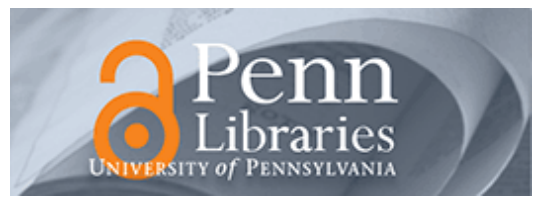

\title{
The Library Chronicle
}

Volume 3 | Number 3

Article 2

October 1935

\section{Shakespeare Books in the Library of the Furness Memorial}

Felix Edward Schelling

Follow this and additional works at: https://repository.upenn.edu/librarychronicle

Part of the Arts and Humanities Commons, and the Library and Information Science Commons

\section{Recommended Citation}

Schelling, F. E. (1935). Shakespeare Books in the Library of the Furness Memorial. : Vol. 3: No. 3. 33-41.

Retrieved from https://repository.upenn.edu/librarychronicle/vol3/iss3/2

This paper is posted at ScholarlyCommons. https://repository.upenn.edu/librarychronicle/vol3/iss3/2

For more information, please contact repository@pobox.upenn.edu. 


\title{
The University of Pennsylonia \\ $\operatorname{LIBR} A R Y$ \\ CHRONICLE
}

Issued Four Times a Year

By and For the Friends of the Library

Of the University of Pennsyluania

C. Seymour Thompson, Editor

\section{SHAKESPEARE BOOKS IN THE LIBRARY OF THE FURNESS MEMORIAL}

\author{
By Dr. Felix E. Schelling
}

I have been asked to describe some of the treasures contained in the Library of the Furness Memorial, and I find the promise to do so far easier than the fulfilment. This for at least two reasons, first the multiplicity and variety of the items in such a collection and, secondly, because of a personal limitation that leaves me cold in the contemplation of what may be called the trappings and insignia of greatness. The world is dotted with mausoleums and museums harboring the relics-better the old word "remains"-of heroes, from the saddle or equine throne of the victor of Agincourt, placed high on a beam in Westminster Abbey, to a replica in waxif report is to be trusted-of the last meal refused by an otherwise indistinguishable youth who gave his name to the foundation of a large American institution of learning. The Furness Memorial contains a number of mementoes: pieces of wood, some expertly fashioned, from the old mulberry tree which, tradition relates, Shakespeare planted with his own hand in 1609 , later chopped down by an irate parson because 
it attracted too many pilgrims to his garden; a splinter of the oaken beam from the room in which the great poet was born; most treasured, a pair of gloves which tradition as far back as Betterton relates were once veritably Shakespeare's. Another kind of interest attaches to the walking stick, deeply carved with the name of Rosalind, which our friend Mr. Otis Skinner once carried when acting Orlando with the celebrated Madame Modjeska; to the set of recorders or flageolets fingered by Booth in Hamlet and declared in the handling "as easy as lying;" the dirk of Macbeth worn by the same great actor; Sir Henry Irving's Shylock's cloak and Hamlet's black shirt; and, last, not least, a skull, inscribed with the names of Keen, Macready, Kemble, and our own Forrest and Booth, which had been tossed out on the stage time out of mind and handled and ruminated upon, abundantly justifying the phrase of the text: "Alas, poor Yorick, I knew him well." My limitation has betrayed me into flippancy, for which, grave reader, be merciful. For those who care for such relics, there are several things worth serious mention in this collection. I must leave to others more sympathetic than I the appreciation which very properly dignifies the collector of them and those who can imaginatively reconstruct the past out of these pathetic remains of them.

Let us turn to the books, which have an entity even apart from association. To begin with the repetition of some of the commonplaces, the famous First Folio, earliest collective edition of Shakespeare's plays, appeared in 1623, seven years after the poet's death. It contained not only a reprint of all, except one, of the plays which had previously appeared in separate quarto editions (seventeen in number), but about as many more which, protected by the King's company who owned the manuscripts, had not previously appeared in print. Naturally this famous book must form the foundation stone of any Shakespeare library; for, as to nearly half the plays, it is the editio princeps; and as to the rest, no matter what the quartos, the Folio is never negligible. The Furness collection contains a good example of this much sought-for volume, 
which is recorded in Lee's "Census of Extant Copies" as having been "well used; Aly-leaf, letterpress of title and last page [however as frequently] made up in facsimile by Harris; the inserted portrait . . . from an original copy." Lee further records that this volume once belonged to Thomas Corser, the well known editor of Collectanea Anglo-Poetica, who acquired his love of Elizabethan literature while at Oxford, in the first decade of the nineteenth century, through intimacy with Dr. Henry Cotton, sub-librarian of the Bodleian, and early became an indefatigable collector of earlier English books. Only one purchaser intervened between Corser and Dr. Furness. This stately volume, in its honestly worn red and gold, declares a long and sturdv aid to scholarship. There could have been none better used among its brethren. The First Folio, despite the eagerness with which it is sought and the notably rising prices which copies of it appear steadily to maintain with the judicious aid of booksellers, is by no means what the bibliophiles would call a rare volume. No less than a hundred and fifty-six copies were listed in various states of completeness as far back as 1902, and something near to two hundred are now known to exist. ${ }^{1}$ Most interesting is it to note that such a survival even of tatterdemalions -until their rags were doffed and they rearrayed as princes -points to two things at least: an original edition not inconsiderable in size-caution forbids the mention of numbers ; $^{2}$ and a popularity which bought up and used this book to its partial destruction. It is the unread book that stands in pristine integrity neglected on the shelves. Popular books are literally read to pieces.

This editio princeps of the collected works of Shakespeare was followed by a second folio in 1632, a third in 1663-64. and a fourth in 1685. Obviously, however, these later editions are less interesting and therefore less valuable, though none is safely to be neglected in questions of text involving

${ }^{1}$ Sidney Lee, Shakespeare's Comedies... a Census, 1902, p. 33; and The Folger Shekespeare Library, 1933, p. 17, where we learn this library has seventy-nine copies. $t: 265$.

${ }^{2}$ See W. W. Greg, "Bibliographical History of First Folio," in The Library, ". s. 
differences and possible corrections. The notion that, in relation to the First Folio and the quartos, these later folios only make a bad matter worse, has long since gone into the discard with other assumptions based on a partial knowledge. ${ }^{3}$ The Furness collection contains good copies of each of the second and third folios, and two of the fourth. An interesting feature of the third folio, as is well known, is the admission into it of seven additional plays not printed in the First Folio. Save for Pericles, which had already appeared in several quartos previously, none of these additions is now accepted as the work of Shakespeare, although a library pro and con on the topic has long since sprung up and faded, to wither on forgotten bookshelves."

The quartos, or single plays, whether printed in the author's lifetime and before the appearance of the First Folio or later, form the second group in a Shakespeare library. Those subsequent to the First Folio are textually of minor value; those before its appearance, never to be neglected. For while it is undoubtedly true that some of these little books of single plays were "stolen and surreptitious copies," we are coming more and more to appreciate the significance of the quartos of Shakespeare which appeared before the date of the poet's death, for it is obvious that there is something to be said for the text of a book which the author might possibly have seen as contrasted with one which he could never have set eyes on; though each case of the Folio versus the quartos is to be judged independently and upon its own merits.

Of the seventeen plays of Shakespeare which appeared in separate or quarto forms before the date of the First Folio, some forty-five separate editions all told, the Furness Library possesses only a few, none of them first editions. Quartos of such quality described in their rarity as literally worth their weight [not in gold but] in "banknotes and those notes by

See a forthcoming study of Shakespeare's Seventeenth-Century Editors, by Black and Shaber, and the earlier authoritative work of A. W. Pollard, Shakespearean Folios and Quartos, 1904.

- See P. Simpson, Proof Reading in the Sixteenth, Sevcnteenth and Eighteenth Centuries, 1935, especially, and the earlier researches of Pollard, Mckerrow, Greg and
many others. 
no means for the smallest sums, "' have long since passed beyond the reach of mere scholarship; to be returned to scholarship's uses, however, by that fine sense of responsibility, of ultimate justice, that has prompted such magnificent foundations as those of the late Henry C. Folger and Henry E. Huntington. For example, there are no two more priceless volumes in all Shakespeariana than the first quarto of Hamlet, 1603, two imperfect copies of which alone are extant-one in the British Museum, the other in the Huntington Library at San Marino, California ${ }^{6}$ and the absolutely unique quarto of Titus Andronicus, earliest play attaching to the name of Shakespeare, now in the Folger Shakespeare Library in Washington. Reproduction of such treasures by our modern means of photostat returns them happily to the uses of scholarship.

To return to the Furness books, this collection possesses twenty-three quartos, according to a census of those printed between 1594 and 1709 prepared some years since. ${ }^{7}$ There are really a few more. They vary in their states of preservation, completeness, and importance: all are of value; some of unusual interest. Somewhat to enumerate, there is a good copy of the third quarto of Hamlet, 1611, the earliest of the eight quartos of this master play in the collection. One of these, undated though possibly of 1630 , exhibits on the title page an imitation of Shakespeare's signature. And it has been identified as one of the many fabricated by the impudent forger W. H. Ireland who, learning when a boy, listening to literary chatter in one of the later decades of the eighteenth century, that the authentic signatures of the great poet were exceedingly few, resolved that such a state of affairs needed remedy. Ireland's forgeries reached to the perpetration of whole plays: but happily they do not concern us. Other valuable quartos of the Furness collection are the Roberts Merchant of Venice, 1600; a Henry $V$ and a King Lear of 1608. All of these may be designated as second quartos. The two

'A Census of Shakespeare's Plays in Quarto, 1916. Introduction, p. ix.

${ }^{6}$ Now admirably reprinted in facsimile by the Huntington Library, 1931.

71. C. Bartlett and A. W. Pollard, A Census of Shakespeare's Plaj's in Quarto, 1916. According to the table on p. $x$ of this work the sum total of first edition quartos is only 146, two of them fragmentary. 
latter are further interesting in that the Henry $V$ is one of several of these volumes presented to Dr. Furness as gifts of friendship by the famous Shakespearean J. O. HalliwellPhillipps, author of the popular Outlines of Shakespeare. Others so presented and inscribed are The Taming of the Shrew, 1631, The Merchant of Venice, 1637, King Lear, 1655, an imperfect copy of the Pericles of 1619, and a fragment of the 1612 quarto of Richard III. The earlier Lear, 1608, mentioned above, contains manuscript notes by Edward Capell, an earlier distinguished editor of Shakespeare: they are unimportant. Finally, the collection includes, besides that mentioned above, another quarto of Pericles, 1630, and the 1631 edition of Love's Labour's Lost, to be designated a second or a third quarto as we reject or accept the theory of a lost first quarto prior to that of 1598 . This item is not mentioned in the "Census." It appears by an inscription to have been "presented to the Shakespeare Society of Philadelphia, March 1870 , by J. O. Halliwell," who had not at that time added "Phillipps" to his name. How it was returned to the Furness Collection we are not informed.

Contemporary Elizabethan books in which there is mention or allusion to Shakespeare form a class eagerly sought for by collectors, and one well represented in this collection. However much we may have seen the quotation in schoolbooks, it is somewhat moving to read, in the swinging balance of Meres' "comparative discourse," Wits Commonvealth (first edition, 1598), how "Shakespeare among the English is most excellent in both kinds for the stage," and to continue through the familiar list of twelve of his plays, already popular at that early date and here printed together for the first time. It is this celebrated passage of contemporary evidence - enough for any court, if insufficient for Baconian or Oxfordian lack-logic-which has been declared by careful skepticism, "our only solid rock in a sea of surmise." But there are other rocks and footholds: witness the grudging jealousy of Greene's Groatsworth of Wit, 1592, Chettle's apology of the next year, Weever's epigram to "honie-tong'd Shakespeare," 
1593, and the scores of others culled for us in the now overgrown Shakespeare Allusion Book. $\quad$ The allusions just named do not exist in this library in their earliest forms; but there are plenty that do: Stowe's Annales, the second edition of which contains an enumeration of "our moderne and present excellent poets . . orderly set down" and among them "Mr. Willi. Shakespeare gentleman:" pray, note "gentleman;" similar lists in Heywood's Rape of Lucrece and Camden's Remains, 1614; Webster's words as to "the right happy and copious industry of Master Shakespeare"-note the "Master" (Vittoria Corombona, 1612); and the delightful passage of Heywood's Hierarchie of the Blessed Angels, 1635, in which, in a muster of good fellowship among the playwrights, each is familiarly docked as to his Christian name, and we read, to quote only a fragment:

"Excellent Bewmont, in the foremost ranke

Of the rar'st Wits, was never more than Frank.

Mellifluous Shakespeare, whose enchanting quill

Commanded mirth and passion, was but Will.

And famous Jonson, though his learned Pen

Be dipt in Castaly, is but Ben."

Leaving much else, we may read in Kirkman's The Wits, 1672 , some of Shakespeare's, with other dramatists,' comedies made over into "drolls," as they were called-about as well as we might dare to do such scenes over into movies-this to escape Puritan penalties in a godly age that consorted ill with such frivolities as stage plays. Will even Mr. Masefield do much better with Romeo and Juliet for the screen? Best among these allusive books I like the fragment of John Wilson's Cheerful Ayres, 1660, which contains the music which Richard Johnson wrote contemporaneously for "Full fathom five thy father lies," Ariel's song in The Tempest. Now, if you will look into any copy of Much Ado About Nothing which has not been sophisticated by modern editing, you will find that (in II, iii) one Jack Wilson enters in the train of the Prince, but that the character, Balthasar (omitted from those

${ }^{8}$ Latest edition that of Sir Edmund Chambers, 2 vol., 1932. 
entering), bandies words and excuses as singers do, and is prevailed upon at last to sing: "Sigh no more, ladies." Wilson is no uncommon name. But is it not pleasurable to believe that young Jack Wilson, singing "Sigh no more, ladies" on the stage in 1599, should have ripened into Dr. John Wilson of Oxford, years later, to collect choice songs out of his memories of the past and include among them the later Shakespeare air, "Full fathom five?" Shall faith and confessions of faith have no more place in scholarship?

We come closer to Shakespeare in the works from which there is reason to believe that he derived his materials. Sources, I do not like to call them; for the mastery of genius does not borrow, but assumes his own wherever he may find it. The Furness collection contains admirable specimens of three of the four cornerstones of Shakespeare's personal library: Holinshed's Chronicles (first edition, 1574), for English history; North's translation of Plutarch (the edition of 1612), for the great men and deeds of the ancient world; Painter's Palace of Pleasure (originally 1575, in this collection only a much later edition), for much of his Italian story; and several fine copies of earlier English Bibles: for Shakespeare, the most untheological of the men of any age, was steeped in the Scriptures. There is also Golding's Metamorphoses of Ovid, 1567, a fine classic spoiled in a clumsy translation: though sensible people no longer question Shakespeare's working competency in the Latin tongue. And there is Florio's Montaigne (in a later edition), of which the honest old counsellor Gonzalo was certainly a reader; Munday's translation of Silvayn's Orator, 1596, which tells (far earlier in the original) "of a Jew, who would for his debt have a pound of the flesh of a Christian;" and the contemporary collections of Belforest's Bandello and Cinthio in their original French and Italian: as to which there are those who conceive that Shakespeare may have been clouded in no such invincible ignorance as not to have been able to use them. Interesting it is to look into The Royal Grammar, "compiled formerly by Mr. William Lilly ... now modestly endeavored 
to be rendered plain and obvious to the capacity of youth." Dr. Lilly was the grandfather of Shakespeare's earlier competitor in the drama, John Lyly. Shakespeare could have studied no other grammar (and grammar was only Latin) if he went to the Stratford Grammar School. Equally well known to him must have been Thomas Wilson's The Arte of Rhetoricke, 1584, from the fertile pages of which it has been thought that Shakespeare derived, among other things, suggestions for the funeral oration of Antony over Caesar's body, the character of Falstaff, and certain petty tricks in punctuation by which a letter may be made to read in divers ways. But enough-there is no end to "the sources of Shakespeare," whether he is conceived of as the least original of petty borrowers or as one who well may have said, with his own Pistol:

"The world's mine oyster!"

We have traversed some distance to reach only the fringe of that tangled and thorny jungle in which cavort the critical editors of Shakespeare. Let us pause before it is too late. The strangest book in any Shakespeare library is one entitled Select Observations on English Bodies of Eminent Persons in desperate Diseases, 1679, by Mr. John Hall, Physician. Hall was Shakespeare's son-in-law and ran true to his calling, immersed in his "cures historical and empirical." Among his patients were many of the nobility or gentry of Warwickshire. We learn of "Mr. Drayton, an excellent poet, laboring of a tertian," and that to his own wife, Elizabeth, Hall administered, among other medicaments and in the resulting cure most successfully, "a pint of sack made hot." This was Falstaff's favorite potation be it remembered, but in no such lady-like proportions. We do not know that Hall ever ministered to the bodily needs of his august father-in-law. But we do know that we would give all his "wormwood, rue and fetherfew," his possets, "gellies of hartshorn with marygold flowers," his "sena cleansed and salt of Tatar" for a paragraph of what he thought of the man whose brain eternized Hamlet, Falstaff, and Cleopatra. 